\title{
UNIVERSITIES-INDUSTRY PARTNERSHIP AND THE DEVELOPMENT OF THE THIRD MISSON OF UNIVERSITIES
}

Universities are institutions where new ideas are developed, new technologies are created, new ways for improving the existing business, economic and other models are explored and developed. Universities are adjusting to the recent changes in the economic environment, and the expectations regarding their contribution to innovation and economic development. They are forced on diversifying their revenue sources, in order to become more efficient and to direct their resources towards greater commercialization of knowledge. As a response, universities are encouraged to become more "entrepreneurial" and cooperate with the industry sector. Entrepreneurial universities have proved to be the organisations where risk-taking is an expected situation when new practices are initiated, and where entrepreneurship is often perceived as implementing an innovative practice in a commercial stage of managing the profit. New universities should be organized so as to reduce the level of bureaucracy that characterizes public organizations and support the commercialization of the ideas generated at universities. Therefore, in this paper, the authors analyse the relationship between the University of Novi Sad (Serbia) and the industry sector, as well as the way in which the employees at the university participate in this cooperation.

Keywords: higher education; entrepreneurial university; industry; third mission; University of Novi Sad (Serbia)

* Faculty of Economics and Engineering Management, University Business Academy in Novi Sad; demirovic.dunja2@gmail.com

** Faculty of Sciences, Department of Geography, Tourism and Hotel Management, University of Novi Sad, Serbia; maja_0206@hotmail.com

*** Faculty of Economics and Engineering Management, University Business Academy in Novi Sad; adrianaradosavac@gmail.com 


\section{Introduction}

Two main trends have contributed to the significant changes in education. The first trend is related to the increasing role and the importance of industrialization and knowledge-based sectors such as entrepreneurship. This leads to a shift from arts and humanities to all areas of natural science, engineering, management and finance. The second one is related to the globalization process, connectivity of markets and increased competition for scarce resources, especially knowledge and human capital. ${ }^{1,2}$ The answer to those new challenges is the policy of academic entrepreneurship. ${ }^{3}$ Instead of changing management and leadership, universities are changing their mission and vision in order to cope with new challenges and changes. As entrepreneurs, universities have to seek opportunities for entering markets and meeting the needs of their stakeholders. ${ }^{4},{ }^{5}$

Academic entrepreneurship is an entrepreneurial mindset and specific behaviour of a university. It is the acceptance of a new concept of thinking with the aim of converting the acquired knowledge in the scientific research process, into a usable product; creating new knowledge and involvement of scientists and research institutions in business. All these activities result in the economic development and growth of the society. Academic entrepreneurship aims to connect basic research processes and practical activities through the process of publishing research findings and their commercialization. Professors, assistants, administrative staff and researchers employed at universities, as well as students who represent an important link in this process are part of an academic entrepreneurship. ${ }^{6}$

An entrepreneurial university is a natural incubator that provides support to employees or students initiating new ventures - intellectual and commercial. An entrepreneurial university should achieve three missions simultaneously, which

Audretsch B. David et al. (2014): „Technology transfer in a global economy”, Journal of Technology Transfer 39(3), 301-312.

2 Ghio Niccolo et al. (2015): “The emergence of the knowledge spillover theory of entrepreneurship”, Small Business Economics 44(1), 1-18.

3 Carlsson Bo et al. (2013): “The evolving domain of entrepreneurship research", Small Business Economics 41(4), 913-930.

4 Thune Taran, Gulbrandsen Magnus (2014): "Dynamics of collaboration in universityindustry partnerships: Do initial conditions explain development patterns?” The Journal of Technology Transfer 39(6), 977-993.

$5 \quad$ Bozeman Barry et al. (2013): "Research collaboration in universities and academic entrepreneurship: The-state-of-the-art", Journal of Technology Transfer 38(1), 1-76.

$6 \quad$ Patzelt Holger, Shepherd A. Dean (2009): "Strategic entrepreneurship at universities: Academic entrepreneurs' assessment of policy programs", Entrepreneurship Theory and practice 33(1), 319-340. 
could otherwise be in conflict with one another: teaching, research and entrepreneurship. $^{7}$

The development of the entrepreneurial university means that in addition to its classic role (transfer of knowledge and research activities) universities have a third mission. It connects the state and environment. The result of this partnership is a new institution and a new connection, enabling the university to become an institution that monitors development in the society and the market. Universities of the third generation will aim at building a partnership network through the competitiveness by integrating two seemingly contradictory activities or concepts - cooperation/collaboration and competition. They should be focused on research and the entrepreneurial ideology of small businesses. Academic entrepreneurship and the creation of spin-off companies are directly responsible for generating income and creating jobs. Due to the current problem of youth employment, the impact that universities can have on their external environment is not negligible.

Entrepreneurship at the university level is also called the third mission of universities. It presents the relationship between the system of higher education institutions and the industry sector that goes beyond the narrow confines of education (expanding of knowledge) and research (primary and secondary mission). ${ }^{8}$

The features of the third mission of universities essentially depend on two main factors: internal (the characteristics of a university as a social subsystem) and external (the characteristics of a social environment). These factors also determine the position of universities in the network of stakeholders in the economic and social entrepreneurship. Given that the modern Serbian society is still in the process of post-socialist transition, and that it is still burdened by a number of structural and functional problems, there is a need to strengthen the third mission of the universities. Based on the foregoing, this paper refers to analysing partnership between the University of Novi Sad (hereinafter: UNS) and the industry sector, as well as the way in which the employees at UNS participate within this cooperation.

Urbano David, Guerrero Maribel (2013): "Entrepreneurial universities socioeconomic impacts of academic entrepreneurship in a European region", Economic Development Quarterly 27 (1), 40-55.

8 Görason Bo et al. (2009): "New activities of universities in transfer and extension: multiple requirements and manifold solutions", Science and Public Policy 36(2), 157-164. 


\section{Theoretical framework}

\subsection{Entrepreneurial orientation of universities}

Entrepreneurial orientation has become an important concept in the literature on entrepreneurship. Some authors ${ }^{9}$ indicate the specific dimensions of entrepreneurial orientation: innovation, risk-taking and proactivity. Universities, in recent times, have been more and more encouraged to be entrepreneurial-oriented. Despite the activities within the university, it is not known enough about the entrepreneurial orientation of departments/faculties/universities, as well as how such orientation can lead to commercial value. The possibility of measuring the entrepreneurial orientation of individual universities and the possibility of comparing the obtained values and finding ways of creating a better entrepreneurial climate at universities are the subjects of several different studies which have used different models and different measurement scales (Table 1). One of them is Entrescale - a scale that measures the performance of a company, especially in an unstable environment. This scale is used as the basis of empirical research on entrepreneurial orientation within the university. Entrescale has a limited application in the non-profit and public sector, and it is not sufficiently examined whether this scale can be used in the process of measuring the entrepreneurial orientation of non-profit and public companies. The differences in objectives, structure and governance of universities can influence the relevant dimensions of what constitutes an entrepreneurial orientation. By using this scale, departments/faculties can develop entrepreneurial spirit, in order to create conditions for the commercialization of the results, such as patenting, licensing, etc. $^{10}$

Entrepreneurial orientation is not the same for the whole university. Some departments/faculties are more entrepreneurial-oriented than others. Universities should form a university culture that would strengthen the entrepreneurial orientation by creating the standards and good examples that would encourage entrepreneurial behaviour.

In an era of economic changes and crisis, universities are changing their strategy of existence, complementing its mission, becoming more efficient and more entrepreneurial, spending more of their resources on the commercialization of knowledge. This strategic venture can have multiple benefits. The entrepreneurial orientation of individual departments/faculties can be measured, as well as the speed at which they commercialize the knowledge. The faculties/

$9 \quad$ Rauch Andreas et al. (2009): Entrepreneurial orientation and business performance: an assessment of past research and suggestions for the future, Entrepreneurship Theory and Practice 33(3), 761-787.

10 Todorovic W. Zelimir et al. (2011): "ENTRE-U: An entrepreneurial orientation scale for universities“, Technovation 31 (2), 128-137. 
departments with a higher grade of entrepreneurial orientation certainly need to have a better position in the environment. Consequently, it should provide additional resources for their further development. Entrepreneurship at universities allows faculties to intensify scientific research and practical projects, ensuring the commercialization of research results and raising the level of entrepreneurial orientation. Entrepreneurial orientation is not only the industrialization of patents and projects and economic development, but it can also be a form of an academic learning through research and practice. ${ }^{11}$

Table 1. Publications regarding the entrepreneurial orientation of universities

\begin{tabular}{|c|c|c|c|c|}
\hline $\begin{array}{l}\text { Authors/Year } \\
\text { of publishing }\end{array}$ & Title & Country & $\begin{array}{l}\text { Basic } \\
\text { methods of } \\
\text { measurement }\end{array}$ & $\begin{array}{l}\text { No. of } \\
\text { factors }\end{array}$ \\
\hline $\begin{array}{l}\text { Todorovic, } \\
\text { McNaughton, } \\
\text { Guild/2010 }\end{array}$ & $\begin{array}{l}\text { ENTRE-U: An } \\
\text { entrepreneurial orientation } \\
\text { scale for universities }\end{array}$ & $\begin{array}{l}\text { the USA, } \\
\text { Canada }\end{array}$ & Likert scale & $23+2$ \\
\hline $\begin{array}{l}\text { Urbano, } \\
\text { Guerrero/2013 }\end{array}$ & $\begin{array}{l}\text { Entrepreneurial } \\
\text { Universities: } \\
\text { Socioeconomic } \\
\text { Impacts of Academic } \\
\text { Entrepreneurship in a } \\
\text { European region } \\
\end{array}$ & Spain & Likert scale & 14 \\
\hline $\begin{array}{l}\text { Goethner, } \\
\text { Obschonka, } \\
\text { Silbereisen, } \\
\text { Cantner/2011 }\end{array}$ & $\begin{array}{l}\text { Scientists' transition } \\
\text { to academic } \\
\text { entrepreneurship: } \\
\text { Economic and } \\
\text { psychological } \\
\text { determinants } \\
\end{array}$ & $\begin{array}{l}\text { Germany, } \\
\text { Denmark }\end{array}$ & Likert scale & 10 \\
\hline $\begin{array}{l}\text { Clarysse, } \\
\text { Tartari, } \\
\text { Salter/2011 }\end{array}$ & $\begin{array}{l}\text { The impact of } \\
\text { entrepreneurial } \\
\text { capacity, experience and } \\
\text { organizational support } \\
\text { on academic } \\
\text { entrepreneurship } \\
\end{array}$ & $\begin{array}{l}\text { the UK, } \\
\text { Belgium }\end{array}$ & Likert scale & 9 \\
\hline $\begin{array}{l}\text { Prodan, } \\
\text { Drnovsek/2010 }\end{array}$ & $\begin{array}{l}\text { Conceptualizing academic- } \\
\text { entrepreneurial intentions: } \\
\text { An empirical test }\end{array}$ & Slovenia & Likert scale & 16 \\
\hline $\begin{array}{l}\text { Vidović, } \\
\text { Bjeliš/2006 }\end{array}$ & $\begin{array}{l}\text { Entrepreneurialism } \\
\text { at the University of } \\
\text { Zagreb: Managing the } \\
\text { sustainability of change }\end{array}$ & Croatia & Likert scale & 10 \\
\hline
\end{tabular}

Todorovic W. Zelimir et al. (2011): "ENTRE-U: An entrepreneurial orientation scale for universities“, Technovation 31 (2), 128-137 
An increasing emphasis is on research and technological development. Universities are now becoming the driving force of economic development of a country. The spread of education and knowledge has become more important and more respected. The mission of a faculty has always been education and science. However, another mission has been evolving over the last two decades. This mission is a response to a constantly changing environment, the internationalization of studies and science, as well as increased competition. An entrepreneurial university has been created through social contacts between the state and universities, or through the link state-industry-science.

\subsection{The role of new universities}

As knowledge is becoming an increasingly important category in today's conditions, new universities are emerging all the time. The quality of knowledge achieved in higher education institutions is becoming increasingly important for national competitiveness. The current focus is on "producing" globally educated citizens. The expectation from universities today - regardless of the geographical location, economic and social factors - is the provision of quality education and training of the future workforce, and the creation of skilled labour. The role of new universities is to produce such academics and graduate students who will have new ideas about new technologies and will be the driving force of the economic and social development. ${ }^{12}$

Universities are being transformed from the institutions that were once exclusively educational-oriented institutions to entrepreneurial-oriented institutions that will certainly make people consider economic consequences of research. The universities across North America, Europe and recently from Asia as well are transferring their activities from educational institutions to entrepreneurial-oriented institutions that emphasize the commercialization of institutional knowledge contributing actively to private enterprises at local and regional level. Some of the factors that can contribute to the success of entrepreneurial-oriented universities are:

- a well-funded and high-quality research that encourages researchers to work on an innovative research and generate products and technologies that can be used in the industry,

- adequate incentives and the participation of faculties in the discovery, protection and commercialization of university inventions.

In order to survive in the global market, universities have to be flexible, and their organizational cultures have to be simple for understanding and accept-

$12 \quad$ Payumo G. Jane et al. (2014): “An entrepreneurial, research-based university model focused on intellectual property management for economic development in emerging economies: the case of Bogor Agricultural University, Indonesia", World Patent Information 36(1), 22-31. 
ance. Additionally, universities should encourage innovation. There are five ways in which academics and scientists can transform and commercialise their research into products and services in the business: ${ }^{13}$

- consulting,

- research companies,

- patents and licenses,

- spin-off companies,

- financing research.

It is immensely important to apply the modern concepts of management and entrepreneurship at higher education institutions. Without these principles there cannot be any development in the organizational context. The concept of innovative adaptation implies the application of strategic entrepreneurship principles and total quality management in every operational process at the higher education institutions. By using the principles of strategic entrepreneurship, higher education institutions will deliver value in an effective manner, while ensuring the delivery of quality management in an efficient manner. This allows a balanced control that guarantees a long-term success of the institution. Since academic entrepreneurship has already affected the economic growth and wealth creation in numerous countries, the policy makers have introduced the measures to support the formation of spin-off ventures at universities. The main objective of these measures is to motivate the employees at universities to become entrepreneurs and create their own ventures. These measures include financing these opportunities and transferring the technology developed at the universities in Europe. ${ }^{14}$

The universities of the third generation will be focused on creating competitiveness, combining two seemingly contradictory activities or concepts - cooperation and competition. They should be focused on entrepreneurial researches and the ideology of a small business.

It is not easy to change the basic role of universities. One of the main problems for the employees at universities is to change the role of the faculties/universities and expand the set of basic activities. However, the changed conditions and the rapid changes in the environment require adaptation and practical knowledge. The students will therefore be able to use such knowledge in everyday business activities.

A number of universities do not realise the importance of the commercialization of research. Some employees still believe that the role of a faculty is not

13 Binkauskas Gintaras (2012): “Academic entrepreneurship: Barriers and fears versus wishes and opportunities", International Journal of Technology Management \& Sustainable Development 11(3), 231-244.

14 Patzelt Holger, Shepherd A. Dean (2009): “Strategic entrepreneurship at universities: Academic entrepreneurs' assessment of policy programs", Entrepreneurship Theory and practice $33(1), 319-340$ 
the commercialization of research. In their opinion, the priorities of educational institutions are studies, research projects, but not their commercialization. The most important problem is the fear of financial failure or unwillingness to risk. Not all people are willing to take risks. The same consern also exists when launching entrepreneurial ventures or starting one's own business. Some faculties are not interested in spending their resources on entrepreneurial ventures. In addition, they believe that private companies will be too dominant during their partnership with universities and will threaten the academic freedom of the staff. ${ }^{15}$ Another problem is an inappropriate technical state and a lack of proper equipment. There is a need for additional training of the experts in various fields who want to become entrepreneurs.

Providing incentives for faculties in the form of awards and necessary resources is one of the best strategic actions for encouraging entrepreneurship at universities. Additionally, the promotion and development of spin-off companies, financed completely or partially by the university or some external source, would significantly encourage entrepreneurship at universities. Scientists can develop their careers and engage in the research simultaneously becoming entrepreneurs. Physical resources are the boundaries between a university and an environment, so it is necessary to provide resources for a university to develop spin-off companies and other forms of academic entrepreneurship. In order to understand how the economy functions, it is necessary to know the cultural, social and political factors that establish institutional dynamics. Entrepreneurial universities can have a social and economic impact on the creation, attraction and retaining entrepreneurs and job seekers. Knowledge is capital, while the forms of knowledge, in this case, are the copyrights, licenses, patents, trademarks and others. ${ }^{16}$

\section{Methodology}

The starting point in designing the questionnaire was HE-Innovate tool, developed by the European Commission and the Organization for Economic Co-operation and Development $(\mathrm{OECD})^{17}$, designed for self-evaluation and mutual comparison of higher education institutions. The questionnaire consists of the statements that are evaluated by using a five-point Likert scale from 1 to 5 (where 1 presents "strongly disagree" and 5 presents "strongly agree"). The ques-

\footnotetext{
15 Bienkowska Dzamila, Klofsten Magnus (2012): “Creating entrepreneurial networks: academic entrepreneurship, mobility and collaboration during $\mathrm{PhD}$ education", Higher Education 64(2), 207-222.

16 Urbano David, Guerrero Maribel (2013): "Entrepreneurial universities socioeconomic impacts of academic entrepreneurship in a European region”, Economic Development Quarterly 27 (1), 40-55.

17 https://heinnovate.eu/ intranet/main/ (September 2016)
} 
tionnaire can be used by individuals or groups of employees, students, stakeholders, etc. The questionnaire consists of seven units and 45 questions.

Given that the experience of the University of Novi Sad is significantly different from the experience and the social conditions of European universities, some alterations have been made in the original instrument for data collection. The questionnaire contained three types of questions: statements with the scale for measuring the strength of attitudes, questions with answers and so-called open-ended questions. Qualitative responses to open-ended questions were used for better understanding of the obtained quantitative results.

This paper analyses only one part of the questionnaire - university-industry partnership. In this part of the questionnaire, it is emphasized that the full potential of the university can be achived only by involving the stakeholders from the public sector, businesses, alumni, professional associations, etc. This section covers the issues concerning the relations between universities/faculties and the stakeholders.

The responses of the employees at the University were collected electronically (by sending a questionnaire via e-mail). In addition to the questionnaire, a cover letter explaining the purpose of the research was attached. The survey was anonymous and based on a voluntary basis. There were 201 respondents, and the survey was conducted from October to December 2016. Statistical Package for Social Sciences (SPSS) used to perform statistical analysis at each faculty, allowing us to compare the results among the faculties. Furthermore, the obtained results enabled a comparison between other universities in the country and abroad.

\section{Results and discussion}

Table 2 presents the structure of the respondents. The total sample consists of 201 respondents. All of the respondents are employed at one of the 12 faculties of the University of Novi Sad (further: UNS).

At the faculty level (dean's office), six professors responded to the survey Three of them were deans and others were vice-deans.

Three of them (50\%) were full professors, two (33.3\%) were assistant professors and one $(16.7 \%)$ was an associate professor. Over $66 \%$ of these respondents were in the age group over 51.

At the department level, 22 professors responded to the survey - 12 of them (54.5\%) were full professors, six (27.3\%) were associate professors and four of them (18.2\%) were assistant professors. The respondents were equally distributed in two age groups - 11 respondents (50\%) were over 51, while 10 respondents were in the category from 41 to 50 years of age.

At the scientific staff level, 173 respondents responded to the survey. As for the title, most of the respondents were assistants (31.8\%), assistant profes- 
sors (27.2\%), full professors (16.8\%) and associate professors (16.2\%). $43.9 \%$ of the respondents were in the age group between 31 and 40 .

Table 2. The structure of the respondents

\begin{tabular}{lcc}
\hline Characteristics & Absolute frequency & Share (\%) \\
\hline Age & 27 & \\
\hline up to 30 & 78 & 13.43 \\
\hline $31-40$ & 50 & 38.80 \\
\hline $41-50$ & 46 & 24.89 \\
\hline over 51 & & 22.88 \\
\hline Title of the respondents & 15 & 7.46 \\
\hline Researcher & 54 & 26.86 \\
\hline Assistant & 52 & 25,87 \\
\hline Assistant professor & 34 & 16.93 \\
\hline Associate professor & 46 & 22.88 \\
\hline Full professor & & \\
\hline Function of the respondents & 6 & 2.99 \\
\hline Dean/Associate Dean & 22 & 10.94 \\
\hline Head of Department & 173 & 86.07 \\
\hline Scientific staff & & \\
\hline Faculty where the respondents work & 2 & 0.99 \\
\hline Academy of Arts & 18 & 8.95 \\
\hline Faculty of Economics & 12 & 5.97 \\
\hline Faculty of Sport and Physical Education & 40 & 19.90 \\
\hline Faculty of Technical Sciences & 4 & 1.99 \\
\hline Faculty of Philosophy & 32 & 15.92 \\
\hline Faculty of Medicine & 17 & 8.46 \\
\hline Faculty of Education & 10 & 4.98 \\
\hline Faculty of Agriculture & 50 & 24.88 \\
\hline Faculty of Sciences & 1 & 0.50 \\
\hline "Mihajlo Pupin" Technical Faculty in & 1 & 0.50 \\
\hline Zrenjanin & 201 & 100 \\
\hline Faculty of Technology & & \\
\hline ian Language & 14 & \\
\hline Total & & \\
\hline & & \\
\hline
\end{tabular}

Source: Authors, Research data 
About $55 \%$ of the respondents completely or partially agree that their faculty is devoted to the cooperation and exchange of knowledge with the economic and public sector. On the other hand, $45.1 \%$ of the respondents believe that their faculty is developing an active partnership in the field of entrepreneurship and is working with a large number of external institutions. The answers to these two questions provide a clear indication that it is necessary for the university to provide continued support to all its faculties and to enable employees to share their professional experience, since various faculties are within UNS.

When asked whether their faculty has strong links with incubators, scienceparks and other external initiatives (thus creating opportunities for a dynamic exchange of knowledge), $68.8 \%$ of the respondents completely or partially disagreed or did not know that mentioned initiatives existed at the faculty level (or in its organizational units) or simply did not have such information. The employees believe that it is necessary for UNS to collect the information and enable cooperation with the above mentioned institutions. The collected information should be available to all the employees. The fact is that the UNS has realized numerous initiatives and cooperation. However, the employees are not familiar with the cooperations and have no information who to contact when it comes to external collaboration.

Approximately $51.4 \%$ of the respondents are aware of the fact that their faculty has been working with the industry, while a large number of employees are not acquainted with the fact whether the faculty cooperates with the economy (37\%). $11.6 \%$ of them think that there is no cooperation between the university and the industry. The answers of the respondents who believe that there are certain forms of cooperation can be classified into several categories: consulting activities, cooperation projects, organizing practice for students, service analysis, measurement and design, organization of training, etc. Consequently, some employees know that some kind of cooperation exists, but do not know what kind of cooperation has been conducted. This means that it is necessary for the faculties and the UNS to constantly promote the cooperation. Moreover, faculties and UNS should engage all the employees in the cooperation with the abovementioned institutions.

Fortunately, 50\% of the respondents at the department level responded that their units provide some opportunities for the participation of their staff and students in entrepreneurial activities with business/external environment and in particular encourage the mobility of their staff and students.

The heads of units are aware that all the parts of the UNS should link research, education and economy (the wider community) in order to affect the entire system of knowledge (68.2\% of the respondents). However, the managers are not able to estimate (40.9\% of the respondents) whether the number of partners of their departments in the field of entrepreneurship has increased over the last 10 years, has stayed the same or has decreased (Figure 1). However, despite the positive 
signals, $50 \%$ of the heads of units considered that their department is not cooperating with the industry. Around 54.5\% of the respondents assessed the quality of cooperation with a high mark of 4 (on the scale from 1 to 5), while the frequency of cooperation is rated with a lower mark -3 (40.9\% of the respondents).

The third group of the participants was composed of the representatives from the faculties' deanery. Four respondents think that their faculties do not facilitate the financing of potential entrepreneurs. In $83.3 \%$ of the cases, there is an opinion that their faculties are devoted to the cooperation and exchange of knowledge with the industry, society and the public sector, while $66.6 \%$ believe that their faculties are actively establishing partnerships in the fields of entrepreneurship and working with a large number of external institutions. 50\% of the respondents stated that their faculties have strong links with incubators, scienceparks and other external initiatives, thus creating opportunities for a dynamic exchange of knowledge. Suprisingly, $50 \%$ of the university leaders considered that their institutions do not provide opportunities for the participation of their staff and students in entrepreneurial activities with business/external environment. The positive fact is that $100 \%$ of the faculty managers considered that the number of partners of their faculties in the field of entrepreneurship over the last 10 years has increased or has remained the same. On the other hand, the deans think there is a significant room for improving the entrepreneurial nature of organizational units at the University of Novi Sad. When asked whether faculties collaborate with industry, $66.7 \%$ answered that they do not cooperate or were not acquainted with the collaboration.

Figure 1. The number of partners in the departments in the field of entrepreneurship for the last 10 years

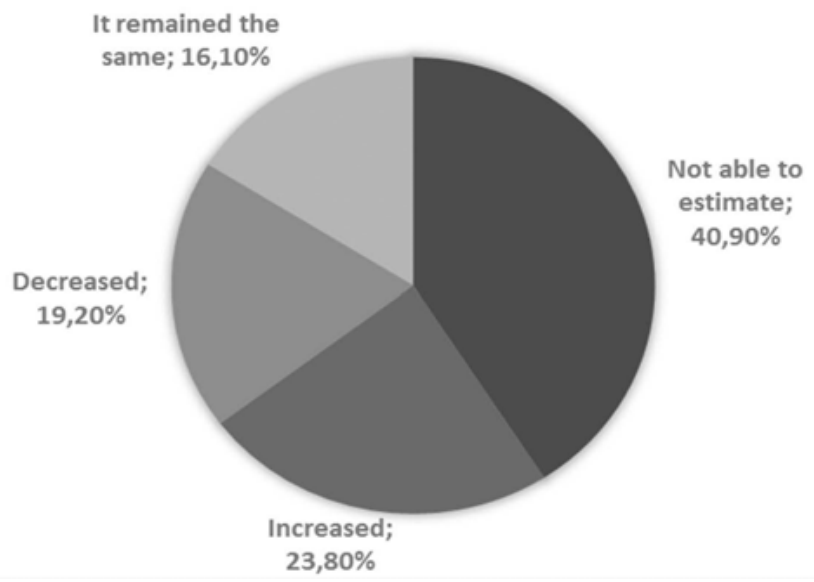

Source: Authors, Research data 
It is noticeable that among the employees at the UNS, regardless of the faculty and the position in the organizational structure, there is a significant critically-oriented group that emphasizes the inadequate development of social entrepreneurship in practice (a total of $29 \%$ of the respondents). It is interesting that every sixth respondent was not able to express a positive or a negative attitude regarding this statement which may indicate that there is an insufficient knowledge, i.e., lack of information on the performance of social functions (Table 3). This result could serve as a warning to the faculties to contribute more to the improvement of the life quality in the community.

Table 3. Attitudes towards the statement "The faculty is involved in solving current social problems" depending on the positions in the management structure of the University of Novi Sad

\begin{tabular}{lcccc}
\hline \multirow{2}{*}{ Attitude } & \multicolumn{3}{c}{ Organizational level (\%) } & Total \\
\cline { 2 - 4 } & Dean's office & $\begin{array}{c}\text { The head of } \\
\text { departments }\end{array}$ & Scientific staff & \\
\hline strongly disagree & 0 & 0 & 5.2 & 4.5 \\
\hline disagree & 0 & 22.7 & 25.6 & 24.6 \\
\hline undecided & 0 & 13.6 & 17.4 & 16.6 \\
\hline agree & 20.0 & 45.5 & 34.9 & 35.7 \\
\hline strongly agree & 80.0 & 18.2 & 16.9 & 18.6 \\
\hline Total & 100.0 & 100.0 & 100.0 & 100.0 \\
\hline
\end{tabular}

Source: The authors, based on the analysis of the data from the survey

The opinion of the employees at the UNS (regardless of the position in the organizational structure) about the statement "The faculty awards prizes to the external (industry) institutions involved in the development of entrepreneurship" are statistically significantly and positively correlated with the attitudes analysed in the following part of the paper. This indicates that the awareness of the active university-industry cooperation is an essential prerequisite for the izbriši the better results of both parties. This is especially confirmed by a high correlation with the attitude "There is cooperation in the field of lectures and learning between the faculty and the industry representative". The value of the correlation coefficient indicates less present cooperation between the faculties and the industry sector (Table 4). 
Table 4. Correlation Matrix

\begin{tabular}{|c|c|c|c|}
\hline & & $\begin{array}{l}\text { The faculty awards } \\
\text { prizes to the } \\
\text { external (industry) } \\
\text { institutions involved } \\
\text { in the development of } \\
\text { entrepreneurship }\end{array}$ & $\begin{array}{l}\text { There is cooperation } \\
\text { in the field of } \\
\text { lectures and learning } \\
\text { between the faculty } \\
\text { and the industry } \\
\text { representatives }\end{array}$ \\
\hline \multirow{3}{*}{$\begin{array}{l}\text { The faculty awards prizes } \\
\text { to the external (industry) } \\
\text { institutions involved } \\
\text { in the development of } \\
\text { entrepreneurship }\end{array}$} & $\mathrm{R}$ & 1 & $.644^{* *}$ \\
\hline & $\mathrm{P}$ & & .000 \\
\hline & $\mathrm{N}$ & 201 & 201 \\
\hline \multirow{3}{*}{$\begin{array}{l}\text { There is cooperation in } \\
\text { the field of lectures and } \\
\text { learning between the } \\
\text { faculty and the industry } \\
\text { representatives }\end{array}$} & $\mathrm{R}$ & $.644^{* *}$ & 1 \\
\hline & $\mathrm{P}$ & .000 & \\
\hline & $\mathrm{N}$ & 201 & 201 \\
\hline
\end{tabular}

${ }^{* *}$ Correlation is significant at the 0.01 level (2-tailed).

Source: The authors, based on the analysis of the data from the survey

Looking at the results of the survey, from the point of the impact of the university on its environment, the surveyed employees do not have a clear opinion whether the faculty continually assesses the impact of its entrepreneurial approach (56\%) and a smaller part considers that it has not been enforced (16\%). The situation is similar when we look at the impact of continuous monitoring and support of the entrepreneurial activities in the region. Regarding the activities of monitoring and evaluation of the activities connected with the transfer of knowledge in the field of entrepreneurship at the university, almost $64 \%$ of the respondents believe that such activities did not exist, and almost 33\% believe that such activities existed, but they have not participated in them. 


\section{Conclusion}

Nowadays, universities are expected to continuously support the entrepreneurial spirit and creativity. Originally, universities were solely focused on educational processes but this situation has changed. It is necessary to reform universities to be more entrepreneurial and to motivate its employees to become entrepreneurial-oriented. An entrepreneurial university should be an institution of the primary importance for a society.

Based on the survey results, as well as the past experience of the professors at the University of Novi Sad, it can be concluded that the management should applay the following rules in the future: improve the quality of teaching at the University, increase the share of practical training in all the courses and encourage knowledge transfer from university to the industry. The quality of teaching has to be improved by increasing the share of practical training during studying at all faculties. A small number of professors cooperate with the industry. Latest world trends show that universities are turning to entrepreneurship. The management of the university (at all levels) should take notice of the encouraging examples of global universities that have specialized services for transferring knowledge and technology within the universities. It can be concluded that the current structure and the system of knowledge transfer are not effective enough and they fail to meet the needs of dynamic technical and technological restructuring adequately.

The development of the university requires much more than a good curriculum. Therefore, internal and external factors are very important since they can transform the role of the university. The basis for further development of the university education can be found in the interaction between university, businesses and government institutions.

The University of Novi Sad should adapt to changes in the environment and become fast and flexible. Academic units of the University of Novi Sad should strive towards entrepreneurial orientation and connectivity with external organizations, resulting in increased revenues and managing important social problems in cooperation with the stakeholders. 


\section{References}

- Audretsch B. David et al. (2014): “Technology transfer in a global economy”, Journal of Technology Transfer 39(3), 301-312.

- Bienkowska Dzamila, Klofsten Magnus (2012): “Creating entrepreneurial networks: academic entrepreneurship, mobility and collaboration during PhD education", Higher Education 64(2), 207-222.

- Binkauskas Gintaras (2012): “Academic entrepreneurship: Barriers and fears versus wishes and opportunities", International Journal of Technology Management \& Sustainable Development 11(3), 231-244.

- Bozeman Barry et al. (2013): "Research collaboration in universities and academic entrepreneurship: The-state-of-the-art", Journal of Technology Transfer 38(1), 1-76.

- Carlsson Bo et al. (2013): "The evolving domain of entrepreneurship research", Small Business Economics 41(4), 913-930.

- Ghio Niccolo et al. (2015): "The emergence of the knowledge spillover theory of entrepreneurship”, Small Business Economics 44(1), 1-18.

- Görason Bo et al. (2009): "New activities of universities in transfer and extension: multiple requirements and manifold solutions", Science and Public Policy 36(2), 157-164.

- Patzelt Holger, Shepherd A. Dean (2009): "Strategic entrepreneurship at universities: Academic entrepreneurs' assessment of policy programs", Entrepreneurship Theory and practice 33(1), 319-340.

- Payumo G. Jane et al. (2014): "An entrepreneurial, research-based university model focused on intellectual property management for economic development in emerging economies: the case of Bogor Agricultural University, Indonesia", World Patent Information 36(1), 22-31.

- Rauch Andreas et al. (2009): "Entrepreneurial orientation and business performance: an assessment of past research and suggestions for the future", Entrepreneurship Theory and Practice 33(3), 761-787.

- Thune Taran, Gulbrandsen Magnus (2014): "Dynamics of collaboration in university-industry partnerships: Do initial conditions explain development patterns?” The Journal of Technology Transfer 39(6), 977-993.

- Todorovic W. Zelimir et al. (2011): "ENTRE-U: An entrepreneurial orientation scale for universities“, Technovation 31 (2), 128-137.

- Urbano David, Guerrero Maribel (2013): "Entrepreneurial universities, socioeconomic impacts of academic entrepreneurship in a European region", Economic Development Quarterly 27 (1), 40-55.

- https://heinnovate.eu/ intranet/main/ (September 2016) 


\section{SARADNJA UNIVERZITETA I INDUSTRIJE KAO FAKTOR RAZVOJA TREĆE MISIJE UNIVERZITETA}

Univerziteti su mesta u kojima se razvijaju nove ideje, stvaraju nove tehnologije, istražuju se i razvijaju novi načini za poboljšanje postojećeg poslovanja, ekonomski $i$ drugi modeli. Univerziteti se prilagođavaju nedavnim promenama u ekonomskom okruženju i očekivanjima za njihov doprinos inovacijama i ekonomskom razvoju. Univerziteti su prisiljeni da diverzifikuju svoje izvore prihoda, postanu efikasniji i usmeravaju resurse ka većoj komercijalizaciji znanja. Kao odgovor, univerziteti se podstiču da postanu "preduzetnički" i sarađuju s industrijskim sektorom. Preduzetnički univerzitet se pokazao kao organizacija u kojoj je preuzimanje rizika normalna pojava kada se iniciraju nove prakse i gde se preduzetništvo često shvata kao primena inovativnih praksi u komercijalnoj fazi eksploatacije dobiti. Novi univerziteti treba da se organizuju kako bi se smanjio nivo birokratije koji karakteriše javne organizacije i tako podrži komercijalizaciju ideja nastalih na univerzitetu. U ovom radu autori analiziraju odnose između Univerziteta $u$ Novom Sadu (Srbija) i industrijskog sektora, kao i način na koji zaposleni na Univerzitetu učestvuju u ovoj saradnji.

Ključne reči: visoko obrazovanje; preduzetnički univerzitet; industrija; treća misija; Univerzitet u Novom Sadu (Srbija) 